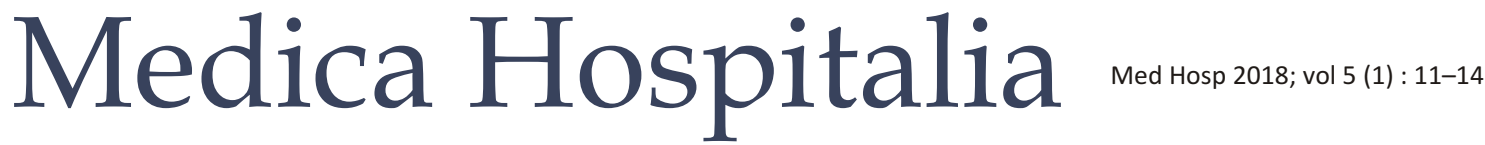

Original Article

\section{Korelasi Kadar Bilirubin Total dengan Estimasi Laju Filtrasi Glomerolus pada Penderita Penyakit Ginjal Kronik}

\author{
Nuraddiyani Hidayah ${ }^{1}$, Ria Triwardhani ${ }^{2}$ \\ ${ }^{1}$ PPDS Patologi Klinik FK UNDIP/RSUP Dr. Kariadi Semarang \\ ${ }^{2}$ Instalasi Laboratorium RSUP Dr. Kariadi Semarang/Bagian Patologi Klinik FK UNDIP
}

\begin{abstract}
Abstrak
Latar belakang : Penyakit Ginjal Kronik (PGK) merupakan gangguan fungsi renal yang progresif dan ireversibel. Estimasi laju filtrasi glomerolus (eLFG) merupakan indeks untuk menilai fungsi ginjal. Stress oksidatif sebagai salah satu penyebab terjadinya disfungsi renal pada PGK. Bilirubin merupakan antioksidan dan mempunyai kemampuan renoprotektif. Tujuan penelitian untuk menganalisis korelasi kadar bilirubin total serum dengan eLFG pada penderita PGK.

Metode : Penelitian belah lintang berdasarkan rekam medik penderita PGK di RSUP Dr. Kariadi pada Agustus 2015 - Juli 2016. Analisis statistik untuk korelasi kadar bilirubin total serum dengan eLFG menggunakan uji korelasi Spearman.

Hasil : Lima puluh dua penderita PGK dengan median (min-maks) kadar bilirubin total serum $0,55(0,22-2,10) \mathrm{mg} / \mathrm{dl}$ dan eLFG 11,75 $(3,4-112,60) \mathrm{ml} /$ menit/1,73m². Uji korelasi Spearman kadar bilirubin total serum dengan eLFG didapatkan $r=0,419 ; p=0,002$. Simpulan : Terdapat korelasi positif sedang yang bermakna antara kadar bilirubin total serum dengan eLFG. Bilirubin mempunyai kemampuan renoprotektif sehingga dengan mengetahui kadar bilirubin total serum dapat membantu mengetahui derajat progresifitas PGK.
\end{abstract}

Kata kunci : penyakit ginjal kronik, bilirubin total serum, eLFG

\section{Correlation of total bilirubin level and estimated glomerular filtration rate in chronic kidney disease patients}

\begin{abstract}
Background : Chronic kidney disease (CKD) is a progressive and irreversible renal dysfunction. Estimated glomerular filtration rate (eGFR) is an index to assess renal function. Oxidative stress as the one of cause the renal dysfunction. Bilirubin is an antioxidant and has renoprotective ability. The aim of research to analyze the correlation serum total bilirubin level with eGFR in chronic kidney disease patients.

Methods : Cross sectional study based on medical record of patients with CKD at Kariadi Hospital Semarang from August 2015 to July 2016. Statistical analysis to correlate serum total bilirubin level with eGFR was performed using Spearman correlation test.

Results : Fifty-two patients with chronic kidney disease, the median of serum total bilirubin level and estimated glomerular filtration rate were $0.55(0.22-2.10) \mathrm{mg} / \mathrm{dl}$ and $11.75(3.4-112.60)$ $\mathrm{ml} / \mathrm{min} / 1,73 \mathrm{~m}^{2}$, respectively. Spearman correlation test between serum total bilirubin level with eGFR was $r=0.419 ; p=0.002$.

Conclusion : There is a moderate positive correlation between serum total bilirubin level with eGFR. Bilirubin has renoprotective capabilities that can help determine the degree of progression in chronic kidney disease patients.
\end{abstract}

Keywords : chronic kidney disease, serum total bilirubin, eGFR

\section{PENDAHULUAN}

Penyakit Ginjal Kronik (PGK) merupakan gangguan fungsi renal yang progresif dan ireversibel dimana tubuh gagal untuk mempertahankan metabolisme serta keseimbangan cairan dan elektrolit sehingga menyebabkan uremia. ${ }^{1,2}$ Riset Kesehatan Dasar (Riskesdas) tahun 2013 menyebutkan bahwa prevalensi gagal ginjal kronik di Indonesia berdasarkan diagnosis dokter sebesar $0,2 \% .^{3}$ Beberapa penelitian sebelumnya 
telah menunjukkan bahwa pada PGK terjadi inflamasi dan stres oksidatif karena ketidakseimbangan yang signifikan antara pro-oksidan dan antioksidan pada pasien dengan disfungsi ginjal. Stres oksidatif pada PGK berbanding terbalik dengan laju filtrasi glomerolus. ${ }^{4,5}$

Estimasi laju filtrasi glomerolus (eLFG) berdasarkan kreatinin serum merupakan pemeriksaan laboratorium untuk menilai fungsi ginjal. ${ }^{6,7}$ Perhitungan eLFG dengan formula Cokcroft-Gault sangat dipengaruhi oleh indeks massa tubuh yang dapat menyebabkan inakurasi pada pasien dengan obese atau edema. ${ }^{8}$ Penelitian oleh Levey AS, et al. (2011) menunjukkan bahwa formula CKD-EPI mempunyai bias lebih rendah dan akurasi lebih baik dibandingkan MDRD. ${ }^{9}$

Bilirubin merupakan produk utama pemecahan sel darah merah oleh sistem retikuloendotelial. Bilirubin terbentuk akibat terbukanya cincin karbon-a dari heme. ${ }^{10}$ Beberapa tahun terakhir ini telah dilakukan penelitian yang menunjukkan bilirubin dapat melindungi terhadap inflamasi pada penyakit kardiovaskuler dan PGK.,11 Hasil penelitian oleh Moolchandani K, et al. (2015) menunjukkan terdapat korelasi positif yang bermakna antara kadar bilirubin total serum dengan eGFR pada penderita PGK. ${ }^{4}$ Penelitian yang dilakukan oleh Lee AT, et al. (2015) menunjukkan peningkatan ringan kadar bilirubin dapat memberikan sifat antioksidan, terkait dengan kemampuannya untuk menghambat oksidasi oleh LDL. ${ }^{11}$

Penyakit ginjal kronik terjadi inflamasi dan stres oksidatif, di mana saat ini penilaian laboratorium fungsi ginjal dengan menggunakan perhitungan formula eLFG. Bilirubin dapat bersifat antioksidan dan mempunyai kemampuan renoprotektif. Bilirubin total serum sebagai parameter laboratorium yang kadarnya diketahui secara langsung dari alat kimia klinik tanpa menggunakan formula perhitungan. Penelitian ini bertujuan untuk mengetahui korelasi kadar bilirubin total serum dengan estimasi laju filtrasi glomerolus (eLFG) pada penderita penyakit ginjal kronik.

\section{METODE}

Penelitian ini merupakan penelitian cross sectional. ${ }^{12}$ Penelitian dilakukan berdasarkan data rekam medik subjek penelitian yang merupakan penderita PGK di RSUP Dr. Kariadi Semarang periode Agustus 2015 - Juli 2016. Kriteria inklusi penelitian adalah penderita penyakit ginjal kronik, pria dan wanita, berusia lebih dari 18 tahun, suhu tubuh normal $\left(36,4-37,2^{\circ} \mathrm{C}\right)$. Pasien dengan penyakit hepar kronik, keganasan atau kelainan hematologi lainnya, pengobatan kemoterapi, infeksi atau penyakit lain yang mengganggu fungsi hepar tidak diikutsertakan dalam penelitian.

Data yang diambil dari rekam medik pasien berupa data anamnesis, pemeriksaan fisik dan laboratorium. Pemeriksaan hitung darah lengkap dari spesimen darah vena dengan antikoagulan EDTA menggunakan alat hematologi otomatik. Pemeriksaan kimia klinik meliputi kreatinin, ureum, bilirubin total, bilirubin direk, SGOT dan SGPT menggunakan serum dengan alat kimia klinik otomatik. Pemeriksaan SGOT dan SGPT untuk menyingkirkan kelainan hepar. Pemeriksaan urinalisis dengan urin analyzer untuk mengetahui petanda kerusakan ginjal. Nilai kreatinin serum selanjutnya digunakan untuk mendapatkan eLFG dengan formula CKD-EPI yang dinyatakan dalam satuan $\mathrm{ml} /$ menit $/ 1,73 \mathrm{~m}^{2}$.

Uji normalitas data menggunakan Kolmogorov Smirnov. Data disajikan dalam bentuk rerata \pm simpang baku untuk data dengan distribusi normal, median (min-maks) untuk data dengan distribusi tidak normal serta persen untuk data kategorikal. Variabel dengan distribusi data yang tidak normal setelah dilakukan transformasi atau syarat uji korelasi Pearson tidak terpenuhi dilakukan uji alternatif korelasi Spearman. ${ }^{13}$ Korelasi kadar bilirubin total serum dengan eLFG menggunakan uji korelasi Spearman. Analisis statistik diolah dengan menggunakan program komputer SPSS 22. Korelasi bermakna secara statistik apabila $p<0,05$. Penelitian ini telah mendapatkan ethical clearance dari Komisi Etik Fakultas Kedokteran Universitas Diponegoro-RSUP Dr. Kariadi Semarang No. 908/ EC/FK-RSDK/IX/2016.

\section{HASIL}

Penelitian ini mengikutsertakan lima puluh dua subjek penelitian yang memenuhi kriteria inklusi dan eksklusi. Karakteristik dasar subjek penelitian dapat dilihat pada tabel 1 .

Subjek terdiri dari 30 pria $(57,69 \%)$ dan 22 wanita $(42,31 \%)$ dengan rerata umur 50,79 $\pm 12,49$ tahun serta rentang umur 20-77 tahun. Rerata nilai kreatinin pada subjek penelitian adalah $5,31 \pm 3,88 \mathrm{mg} / \mathrm{dl}$. Pada uji normalitas dihasilkan kadar bilirubin total serum dan nilai eLFG tidak berdistribusi normal sehingga disajikan dalam median (min-maks) berturut-turut yaitu 0,55 $(0,22-2,10) \mathrm{mg} / \mathrm{dl}$ dan $11,75(3,4-112,60)$ $\mathrm{ml} / \mathrm{menit} / 1,73 \mathrm{~m} 2$. Nilai eLFG subjek penelitian menunjukkan jumlah penderita PGK dengan eLFG $>60 \mathrm{ml} /$ menit $/ 1,73 \mathrm{~m}^{2}$ yang disertai dengan proteinuria adalah 9 orang $(17,30 \%)$, sedangkan jumlah penderita PGK dengan eLFG $<60 \mathrm{ml} /$ menit/1,73 $\mathrm{m}^{2}$ adalah 43 orang $(82,70 \%)$.

Tabel 2 menunjukkan hasil dari penelitian ini yaitu terdapat korelasi positif sedang yang bermakna antara kadar bilirubin total serum dengan eLFG $(r=0,419$; $p=0,002$ ).

Gambar 1 menunjukkan kemiringan garis merupakan kekuatan hubungan yaitu semakin miring garis bearti semakin kuat korelasi antara kadar bilirubin total serum dengan eLFG. Data tersebar yang mendekati 


\section{TABEL 1}

\section{Karakteristik dasar subjek penelitian}

\begin{tabular}{ll} 
Karakteristik subjek & $\mathbf{n}(\%)$ \\
\hline Umur (tahun) & \\
Jenis kelamin & \\
$\quad$ Pria & $30(57,69)$ \\
$\quad$ Wanita & $22(42,31)$ \\
Hipertensi & $38(73,07)$
\end{tabular}

Hemoglobin $(\mathrm{g} / \mathrm{dl})$

Jumlah leukosit $\left(\times 10^{3} / \mu l\right)$

Jumlah trombosit $\left(x 10^{3} / \mu l\right)$

Ureum (mg/dl)

Kreatinin (mg/dl)

eLFG (ml/menit/1,73m²)

Bilirubin total (mg/dl)

Bilirubin direk (mg/dl)
Rerata \pm SB

$50,79 \pm 12,49$

11,1
$9,74 \pm 2,07$

$8,50 \pm 2,55$

$245,39 \pm 123,57$

$5,31 \pm 3,88$
106 (14-305)

$11,75(3,4-112,60)$

$0,55(0,22-2,10)$

$0,23(0,03-1,61)$

\section{TABEL 2}

\section{Korelasi bilirubin total serum dengan eLFG}

\section{Parameter}

eLFG

\begin{tabular}{ccc} 
& r & $\boldsymbol{p}$ \\
\hline Bilirubin total serum & 0,419 & $0,002^{*}$ \\
\hline
\end{tabular}

Uji korelasi Spearman, ${ }^{*}$ ) signifikan $p<0,05$

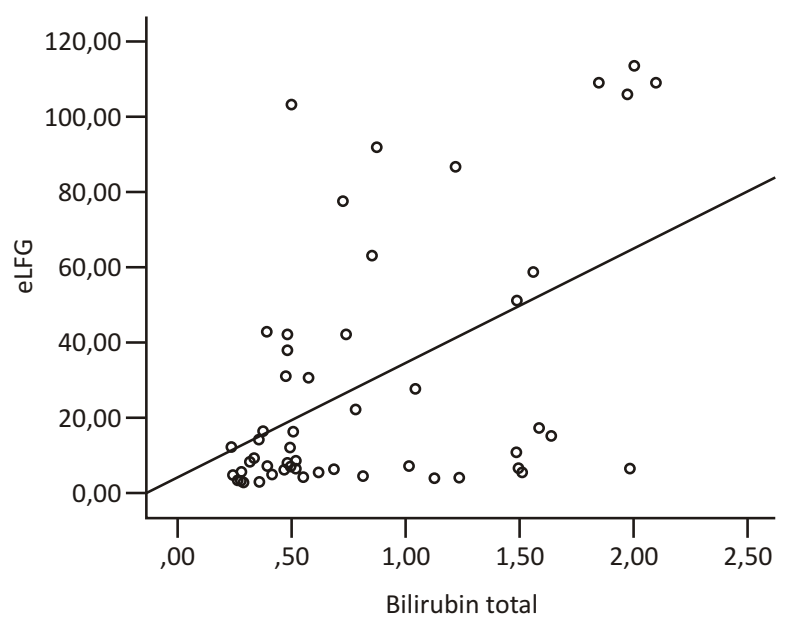

Gambar 1. Diagram sebar hubungan bilirubin total serum dengan eLFG garis juga menunjukkan kekuatan hubungan.

\section{DISKUSI}

Korelasi positif yang bermakna antara kadar bilirubin total serum dengan eLFG pada penelitian ini sesuai dengan penelitian sebelumnya yang menyatakan bahwa bilirubin mempunyai efek renoprotektif., ${ }^{4,11}$ Beberapa mekanisme yang dapat menjelaskan yaitu bilirubin merupakan produk akhir dari katabolisme heme oleh heme oxygenase $(\mathrm{HO})$ dan telah dikatakan bahwa bilirubin sebagai antioksidan endogen dalam tubuh manusia. Berkurangnya kadar HO-1 dapat menyebabkan peningkatan produksi Reactive Oxygen Species (ROS). Stres oksidatif terjadi pada disfungsi ginjal dan berpengaruh terhadap progresifitas PGK. Peningkatan ringan kadar bilirubin serum dapat mencegah terjadinya PGK.

Abnormalitas lipoprotein merupakan faktor predisposisi aterosklerosis dan dapat menyebabkan perkembangan PGK. Bilirubin berkorelasi positif dengan HDL, namun berkorelasi negatif dengan peningkatan trigliserida dan small dense- $L D L$ dengan demikian bilirubin mempunyai kemampuan protektif terhadap ginjal. Diabetes melitus (DM) merupakan salah satu faktor risiko penting terjadinya PGK. Penelitian sebelumnya menunjukkan bahwa kadar bilirubin serum yang lebih tinggi memberikan efek perlindungan terhadap DM dan memprediksi risiko penurunan DM tipe 2 dan nefropati diabetik.

Beberapa penelitian epidemiologis telah 
menemukan bahwa inflamasi mempunyai peran dalam patogenesis PGK. Beberapa biomarker inflamasi, termasuk CRP dan sitokin pro-inflamasi, terbukti terkait dengan kelainan fungsi ginjal. ${ }^{11}$

\section{SIMPULAN}

Penelitian ini membuktikan terdapat korelasi positif sedang yang bermakna antara kadar bilirubin total serum dengan eLFG. Hal ini menunjukkan bahwa bilirubin sebagai antioksidan dan mempunyai kemampuan renoprotektif. Pemeriksaan kadar bilirubin total serum dapat membantu mengetahui derajat progresifitas PGK. Peneliti menyarankan adanya penelitian lebih lanjut mengenai kemampuan bilirubin sebagai prediktor terhadap kejadian PGK.

\section{DAFTAR ISI}

1. Vallet M, Metzger M, Haymann JP, Flamant M, Gauci C, Thervet $\mathrm{E}$, et al. Pathogenesis, consequences, and treatment of metabolic acidosis in chronic kidney disease. Kidney Int. 2015; 88(1): 137-45.

2. Kasiske B. Guideline on CKD. Diunduh dari : http:/ / www.kdigo.org/Clinical\%20Practice\%20Conferences / Philippines\%202014/KDIGO\%20CKD\%20Guideline\%20Manila _Kasiske.pdf. tanggal 5 September 2016.
3. Badan Penelitian Dan Pengembangan Kesehatan Kementerian Kesehatan RI. Riset Kesehatan Dasar (RISKESDAS) 2013. Diunduh dari : http://terbitan.litbang.depkes.go.id/ penerbitan/index.php/blp/catalog/book/64. tanggal 26 Juli 2016.

4. Moolchandani K, Priyadarssini M, Rajappa M, Parameswaran S, Revathy G. Serum bilirubin : a simple routine surrogate marker of the progression of chronic kidney disease. British Journal of Biomedical Science 2016; 73(4): 188-93.

5. Kao MP, Ang DS, Pall A, Struthers AD. Oxidative stres in renal dysfunction: mechanisms, clinical sequelae and therapeutic options. J Hum Hypertens 2010; 24:1-8.

6. Carroll LE. The Stage of Chronic Kidney Disease and the Estimated Glomerular Filtration Rate. The Journal of Lancaster General Hospital, 2006; 1(2): 64-9.

7. Afiatin, Roesli RMA. Laju Filtrasi Glomerolus dengan Metode eGFR. Diunduh dari : http://www.pustaka.unpad.ac.id/ wpcontent/uploads/2009/10/laju_filtrasi_ glomerulus.pdf. tanggal 26 Juli 2016.

8. Dewi PY. Performa Formula Cockcroft-Gault, MDRD dan CKD EPI. Diunduh dari : https://www.researchgate.net/ publication/277006881. tanggal 26 Juli 2016.

9. Levey AS, Stevens LA, Schmid CH, Zhang YL, Castro AF, Feldman HI. A new equation to estimate glomerular filtration rate. Ann Intern Med. 2011;155(6): 408.

10. Bakta IM. Hematologi Klinik Ringkas. Jakarta : Penerbit Buku Kedokteran EGC 2006: 50-80.

11. Lee AT, Wang YY, Lin SY, Liang JT, Sheu WH, Song Y, et al. Higher serum total bilirubin concentration is associated with lower risk of renal insufficiency in an adult population. Int J. Clin Exp Med 2015; 8(10): 19211-2. 